\title{
Liquid Infiltration of Porous Calcium Hydroxide Solid for Synthesizing Bulk Calcium Phosphate Biomaterials
}

\author{
Jyun-Cing Cao, Tze-Wei Chang, Chun-Yen Chiang, Jaine-Huai Huang, Tzer-Shin Sheu* \\ Department of Materials Science \& Engineering, I-Shou University, Taiwan
}

Copyright $\subset 2016$ by authors, all rights reserved. Authors agree that this article remains permanently open access under the terms of the Creative Commons Attribution License 4.0 International License

\begin{abstract}
Bulk calcium phosphate biomaterials without sintering were synthesized at room temperature by infiltrating various orthophosphate aqueous solutions into a porous $\mathrm{Ca}(\mathrm{OH})_{2}$ green powder compact. These orthophosphate aqueous solutions were prepared from a different ratio of $\mathrm{Ca}(\mathrm{OH})_{2} / \mathrm{H}_{3} \mathrm{PO}_{4}$ up to $\mathrm{pH}=12$. The infiltrated specimens did not show any shape or dimension changes at a lower concentration of $\mathrm{H}_{3} \mathrm{PO}_{4}$ or a liquid with $\mathrm{pH}>2$. When the liquid contained some supersaturated solids or precipitates, the infiltrated specimens showed their reacted phases at the surface similar to these supersaturated precipitates, which were $\mathrm{Ca}\left(\mathrm{H}_{2} \mathrm{PO}_{4}\right)_{2} \cdot \mathrm{H}_{2} \mathrm{O}$ (MCPM), $\mathrm{CaHPO}_{4} \cdot 2 \mathrm{H}_{2} \mathrm{O}(\mathrm{DCPD})$, or $\mathrm{Ca}_{10}\left(\mathrm{PO}_{4}\right)_{6}(\mathrm{OH})_{2}(\mathrm{HA})$ as $\mathrm{pH}$ was increasing. Under a liquid infiltration with a lower concentration of $\mathrm{H}_{3} \mathrm{PO}_{4}$ liquid, a functional graded calcium orthophosphate composite was observed. Furthermore, relationships among processing factors like $\mathrm{pH}$ plus impurities and liquid concentration, phase formation, and microstructure of infiltrated specimens were discussed in detail.
\end{abstract}

Keywords Calcium Phosphate, Liquid Infiltration, Reaction Formation, Biomaterial

\section{Introduction}

A ternary system $\mathrm{Ca}(\mathrm{OH})_{2}-\mathrm{H}_{3} \mathrm{PO}_{4}-\mathrm{H}_{2} \mathrm{O}$ has been extensively studied for preparing calcium orthophosphate materials, especially in powder fabrication [1-7]. In the aqueous solution, most calcium orthophosphates being observed are MCPM (monocalcium phosphate monohydrate, $\mathrm{Ca}\left(\mathrm{H}_{2} \mathrm{PO}_{4}\right)_{2} \cdot \mathrm{H}_{2} \mathrm{O}$ ), DCPD (dicalcium phosphate dihydrate, $\mathrm{CaHPO}_{4} \cdot 2 \mathrm{H}_{2} \mathrm{O}$ ), and HA (hydroxyapatite, $\left.\mathrm{Ca}_{10}\left(\mathrm{PO}_{4}\right)_{6}(\mathrm{OH})_{2}\right)$ etc., which are dependent of $\mathrm{pH}$, concentration of ions $\mathrm{Ca}^{2+}$, and $\mathrm{P}^{5+}$ or $\mathrm{PO}_{4}{ }^{3-}$ during the processes. Some other orthophosphates, such as $\mathrm{OCP}$ (octacalcium phosphate, $\left.\mathrm{Ca}_{8}\left(\mathrm{HPO}_{4}\right)_{2}\left(\mathrm{PO}_{4}\right)_{4} 5 \mathrm{H}_{2} \mathrm{O}\right)$ and $\mathrm{CDHA}($ calcium-deficient hydroxyapatite, $\left.\mathrm{Ca}_{10-\mathrm{x}}\left(\mathrm{HPO}_{4}\right)_{\mathrm{x}}\left(\mathrm{PO}_{4}\right)_{6-\mathrm{x}}(\mathrm{OH})_{2-\mathrm{x}}, 0<\mathrm{x}<1\right)$, are believed to be intermediate, metastable, or other derivative phases [1,8-12]. However, not every orthophosphate is already being well-defined in its formation; therefore, some of these orthophosphate phases are still under investigation.

Based on the previous findings, different calcium orthophosphate powders are very easy to obtain in the $\mathrm{Ca}(\mathrm{OH})_{2}-\mathrm{H}_{3} \mathrm{PO}_{4}-\mathrm{H}_{2} \mathrm{O}$ ternary system. In this study, we will use an alternative way to prepare a bulk calcium orthophosphate composite instead of a powder form. This is because a chunk of reacted or unreacted $\mathrm{Ca}(\mathrm{OH})_{2}$ solid form is frequently found if the $\mathrm{Ca}(\mathrm{OH})_{2} / \mathrm{H}_{3} \mathrm{PO}_{4}$ aqueous solution is not well mixed [7]. Even though this phenomenon is a shortcoming for powder preparation, but it may be a convenient way to obtain a bulk calcium phosphate composite at room temperature. Therefore, a porous $\mathrm{Ca}(\mathrm{OH})_{2}$ green powder compact is designed to infiltrate the supersaturated orthophosphate aqueous solution, in which phosphate ions such as $\mathrm{H}_{2} \mathrm{PO}_{4}{ }^{-}, \mathrm{HPO}_{4}{ }^{2-}$, or $\mathrm{PO}_{4}{ }^{3-}$ are phase equilibrated or coexist with their related calcium orthophosphates. It is hoped that a bulk porous calcium phosphate composite is obtained through this liquid infiltration method for orthopedic or other related applications. Furthermore, phases and microstructures of infiltrated specimens are also observed to explain the possible reaction mechanisms of this liquid infiltration.

\section{Materials and Methods}

Starting chemicals were $\mathrm{Ca}(\mathrm{OH})_{2}(95 \%$ pure, Nippon Shiyaku Kogyo K.K., Osaka, Japan), $\mathrm{H}_{3} \mathrm{PO}_{4}$ (85\% pure, Union Chemical Work LTD, Hsinchu, Taiwan), $\mathrm{NH}_{4} \mathrm{OH}$ (28\% pure, Nippon Shiyaku Kogyo K.K., Osaka, Japan). These starting chemicals were used to prepare a porous $\mathrm{Ca}(\mathrm{OH})_{2}$ green powder compact or a specific type of orthophosphate aqueous solution up to $\mathrm{pH}=12$.

\subsection{Preparations of Porous $\mathrm{Ca}(\mathrm{OH})_{2}$ Green Powder Compacts and Orthophosphate Aqueous Solutions}

A porous $\mathrm{Ca}(\mathrm{OH})_{2}$ green powder compact, with the cylindrical dimension of $\varphi 1.2 \mathrm{~cm}$ (D) $\times \sim 0.3 \mathrm{~cm}$ (T) (D, 
diameter; $\mathrm{T}$, thickness), was formed from a batch of $0.5 \mathrm{~g}$ $\mathrm{Ca}(\mathrm{OH})_{2}$ initial powder inside a cylindrical stainless steel die under a uniaxial compressive stress up to $22 \mathrm{Kg} / \mathrm{cm}^{2}$, to obtain a porosity up to $30 \mathrm{vol} \%$.

As to a specific orthophosphate aqueous solution at a different $\mathrm{pH}$ up to $\mathrm{pH}=12$, it was obtained from the different portions of $\mathrm{Ca}(\mathrm{OH})_{2}$ and $0.06 \mathrm{M}$ or $1.2 \mathrm{MH}_{3} \mathrm{PO}_{4}$, as listed in Table 1, by mixing and also staying-put over a day to observe any $\mathrm{pH}$ change. The $\mathrm{pH}$ values of these orthophosphate aqueous solutions were measured by using a pH meter (PHM 210 Standard $\mathrm{pH}$ Meter, Radiometer Analytical SAS, Villeurbanne Cedex, France).

Table 1. Different orthophosphate solutions for liquid infiltration

\begin{tabular}{|c|c|c|c|c|}
\hline \multirow{2}{*}{$\begin{array}{l}\text { orthophosphate } \\
\text { solution }\end{array}$} & \multicolumn{2}{|c|}{$\mathrm{H}_{3} \mathrm{PO}_{4}(\mathrm{ml})$} & \multirow{2}{*}{$\begin{array}{c}\mathrm{Ca}(\mathrm{OH})_{2} \\
(\mathrm{~g})\end{array}$} & \multirow{2}{*}{$\mathrm{pH}$} \\
\hline & $1.2 \mathrm{M}$ & $0.06 \mathrm{M}$ & & \\
\hline LP & & 100 & 0.0 & 1.89 \\
\hline LP2 & & 100 & 0.040 & 2 \\
\hline LP4 & & 100 & 0.225 & 4 \\
\hline LP6 & & 100 & 0.44 & 6 \\
\hline LP8 & & 100 & 0.47 & 8 \\
\hline LP10 & & 100 & 0.51 & 10 \\
\hline LP12 & & 100 & 0.58 & 12 \\
\hline HP & 100.0 & & 0.0 & 1.03 \\
\hline HP2 & 165.0 & & 5.0 & 2 \\
\hline HP4 & 55.5 & & 5.0 & 4 \\
\hline HP6 & 37.5 & & 5.0 & 6 \\
\hline HP8 & 35.0 & & 5.0 & 8 \\
\hline HP10 & 33.5 & & 5.0 & 10 \\
\hline HP12 & 28.0 & & 5.0 & 12 \\
\hline
\end{tabular}

\subsection{Liquid Infiltration}

A $0.5 \mathrm{~g} \mathrm{Ca}(\mathrm{OH})_{2}$ green powder compact was submerged into a specific orthophosphate solution at room temperature for $1 \mathrm{~h}$ up to 1 week to observe its liquid infiltration phenomena and $\mathrm{pH}$ changes. From preliminarily observations, there were no any significant $\mathrm{pH}$ changes before and after liquid infiltration.

\subsection{Phase Determination and Microstructure Observations}

Phase existence of infiltrated samples or initial powders were determined from X-ray diffraction patterns (XRDs) at room temperature by using an X-ray unit (X'Pert PRO, PANalytical Inc., Netherlands) at $2 \theta=20-80^{\circ}$, with a scanning speed of $3 \% \mathrm{~min}$ and a sampling interval of $\Delta \theta=0.04^{\circ}$. For microstructure observations, a field emission scanning electron microscope (FE-SEM, S-4700, Hitachi Inc., Germany) was used to observe the free surface or facture surface of infiltrated specimen.

\section{Results}

\subsection{Macrographs and phase existence of liquid infiltrated specimens.}

Macrographs of liquid infiltrated specimens are shown in Fig. 1. From these optical macrographs, the $\mathrm{Ca}(\mathrm{OH})_{2}$ powder compact is completely dissolved in the HP solution, but slightly dissolved in the HP2 solution because its dimension is a little smaller than the original, as shown in Fig. 1. Therefore, $\mathrm{Ca}(\mathrm{OH})_{2}$ powder compacts are very easy to dissolve in the higher concentrated $\mathrm{H}_{3} \mathrm{PO}_{4}$, but not in the lower concentration of $\mathrm{H}_{3} \mathrm{PO}_{4}$. However, the rest samples at higher $\mathrm{pHs}$ do not show any significant dimension changes. It indicates that the transformed phases inside the infiltrated specimen can be bonded together without any significant dimension change, even though the initial $\mathrm{Ca}(\mathrm{OH})_{2}$ powder compact is simply mechanically-bonded.

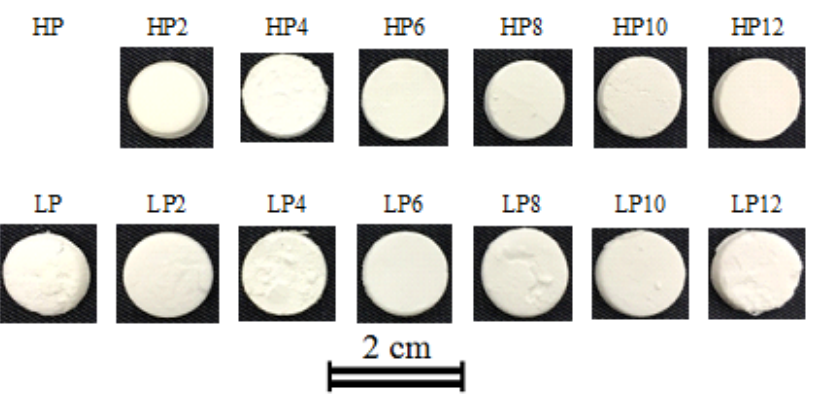

Figure 1. Optical macrographs of infiltrated $\mathrm{Ca}(\mathrm{OH})_{2}$ specimens after being treated in different orthophosphate solutions HP-HP12 and LP-LP12.

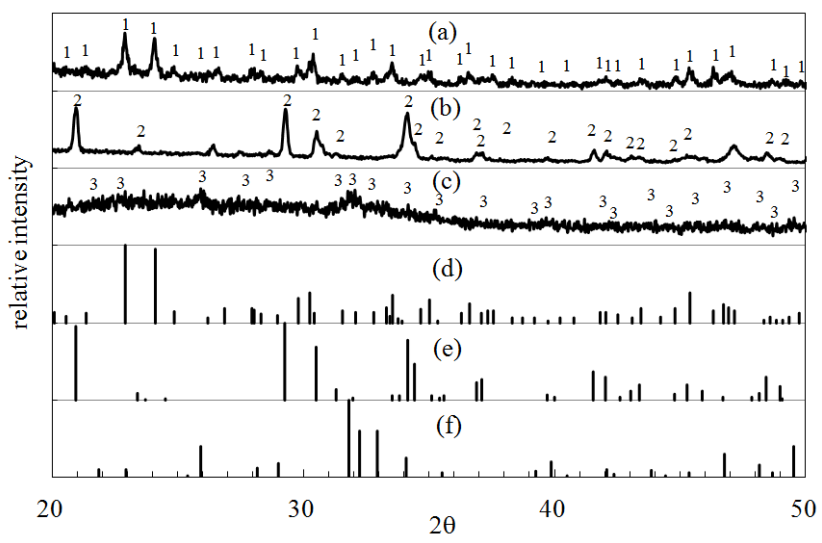

Figure 2. X-ray diffraction patterns at the surfaces of infiltrated specimens (a) LP, (b) LP4, (c) LP10, (d) MCPM (JCPDS 09-0347), (e) DCPD (JCPDS 09-0077), (f) HA (JCPDS 09-0432). Symbols "1", “2", and "3" are for MCPM, DCPD, and HA, respectively.

X-ray diffraction patterns (XRDs) at the surface of the infiltrated specimens are selectively shown in Fig. 2. From these XRDs, phases at the infiltrated surfaces are MCPM, DCPD, and HA as the $\mathrm{pH}$ value of infiltrated aqueous solution increases. MCPM exists in the infiltrated specimen LP; DCPD is present in the infiltrated specimens HP2-HP6 and LP2-LP6. However, HA is formed in the infiltrated 
specimens HP8-HP12 and LP8-LP12. There are no any trace of $\mathrm{Ca}(\mathrm{OH})_{2} \mathrm{X}$-ray diffraction peaks being observed on the surface of these infiltrated specimens. Therefore, the initial $\mathrm{Ca}(\mathrm{OH})_{2}$ powder on the surface is already completely transformed into new calcium orthophosphate phases after liquid infiltration. (a)

(c)

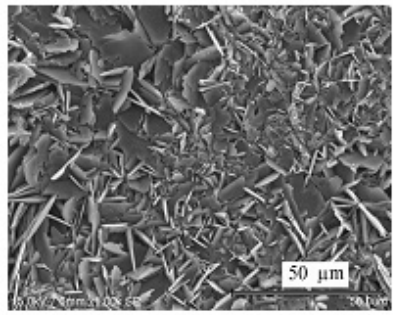

(e)

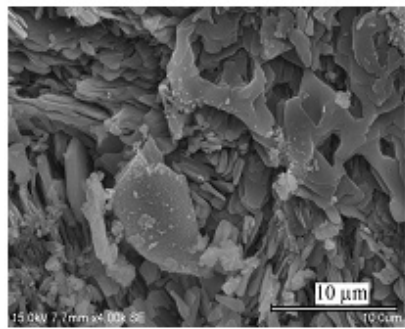

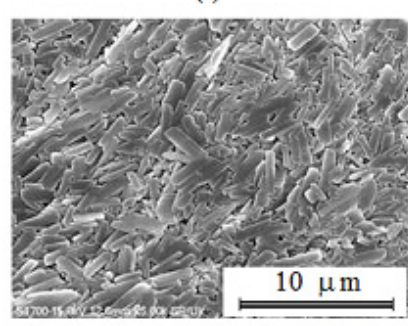

(b)

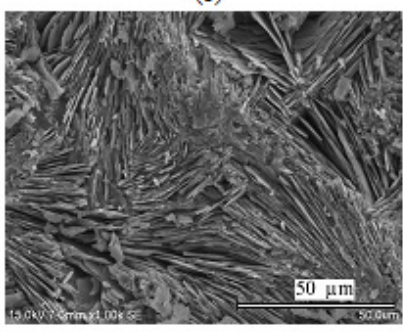

(d)

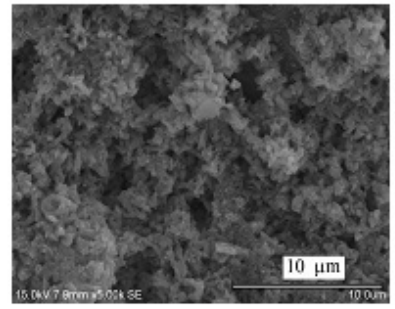

(f)

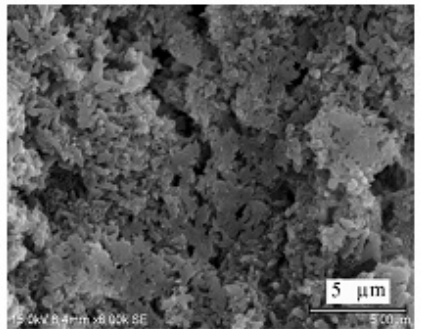

Figure 3. SEM micrographs at the surfaces of infiltrated specimens (a)LP, (b)LP2, (c)LP4, (d) LP12, (e)HP2, and (f)HP10.

\subsection{Microstructures of Liquid-infiltrated Specimens}

(a) Microstructures on the infiltrated surface.

SEM micrographs of infiltrated specimens at the surface are representatively shown in Fig. 3. It indicates that calcium orthophosphates grow faster at a low $\mathrm{pH}$ value. This phenomenon also can be seen from the corresponding X-ray diffraction patterns, as shown in Fig. 2. Calcium hydroxyapatite (HA) crystals shown in Fig. 2(c) have much broader diffraction peaks, which demonstrate HA having much smaller grains or domains, if compared with Figs. 2(a) \& 2(b). At lower pHs, calcium orthophosphates are plate-like for MCPM and DCPD. However, at higher pHs, HA seems shows ellipsoid-like morphologies.

(b) Fractographs perpendicular to the infiltration surface.

In the LP solution $\left(\mathrm{Ca}(\mathrm{OH})_{2} / 0.06 \mathrm{MH}_{3} \mathrm{PO}_{4}\right.$ system), a fractograph of infiltrated specimen perpendicular to the free surface is shown in Fig. 4(a). Free surface or the infiltrated surface contains several large holes, which were produced from the chemical reaction between the $\mathrm{Ca}(\mathrm{OH})_{2}$ powders and $\mathrm{H}_{3} \mathrm{PO}_{4}$, but not from the original pores. Except for the free surface, several different facture morphologies, upper area, transition zone, plus lower area in the reacted zone, and unreacted zone are defined in this fractograph. This is because these areas have different contents of $\mathrm{Ca}, \mathrm{P}$, and $\mathrm{O}$ elements, as shown in Figs. 4(b), (c), \& (d). Based on the trace content of $\mathrm{P}$, the unreacted zone is identified to be the location of the original $\mathrm{Ca}(\mathrm{OH})_{2}$ powders, which are not being liquid infiltrated. As to the reacted zone, the upper area has a higher $\mathrm{P}$ content, but a lower Ca content if compared it with the lower area.

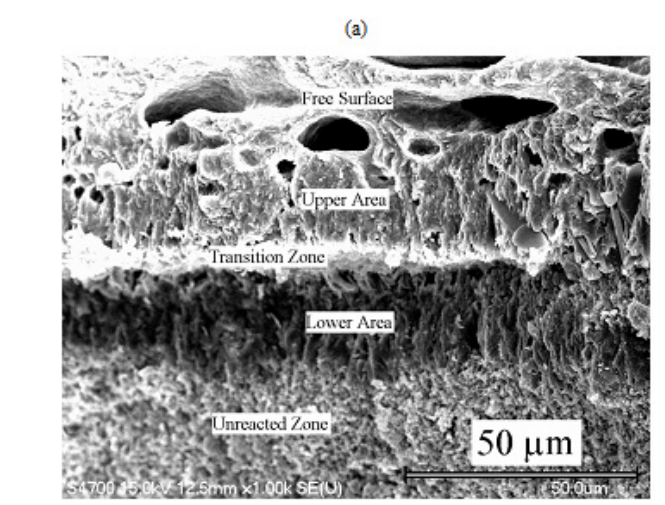

(b)

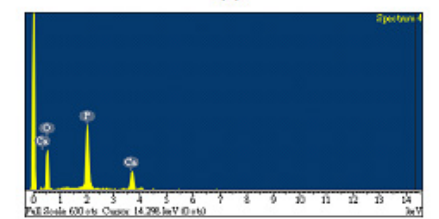

(c)
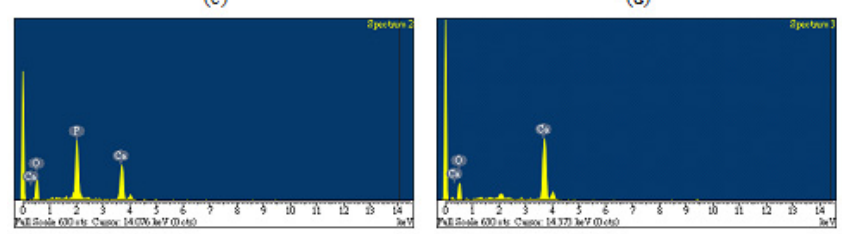

Figure 4. (a)A fractograph perpendicular to the free surface of infiltrated specimen LP, and its EDXS in the (b) upper area, (c) lower area, and (d) unreacted zone.

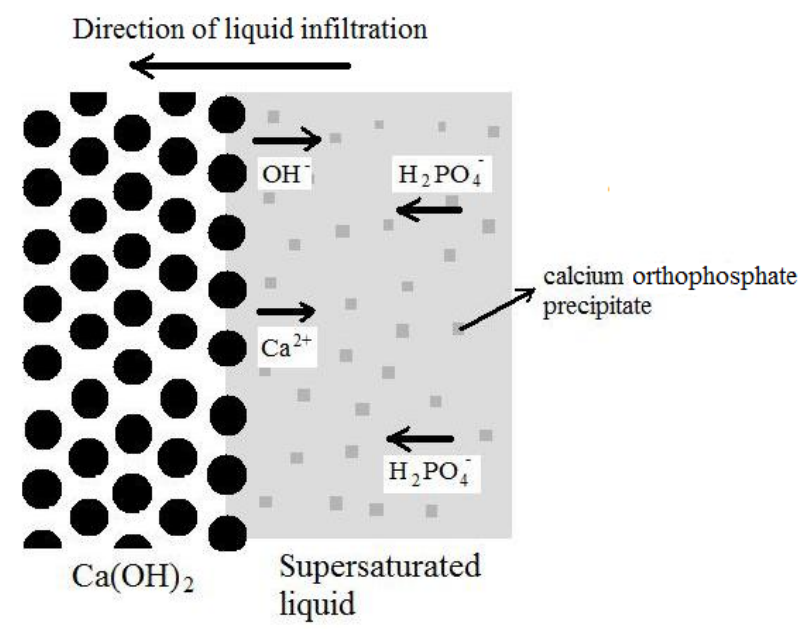

Figure 5. A schematic diagram of solid/liquid interface in the liquid infiltration front. 


\section{Discussion}

\subsection{Liquid Infiltration}

In the $\mathrm{Ca}(\mathrm{OH})_{2}-\mathrm{H}_{3} \mathrm{PO}_{4}-\mathrm{H}_{2} \mathrm{O}$ system, phase existence is correlated with $\mathrm{pH}$, temperature, and concentration of $\mathrm{Ca}^{2+}$, $\mathrm{H}_{2} \mathrm{PO}_{4}^{-}, \mathrm{HPO}_{4}{ }^{2-}$, and $\mathrm{PO}_{4}{ }^{3-}[3,5,6,13]$. As to the liquid infiltration of $\mathrm{Ca}(\mathrm{OH})_{2} / \mathrm{H}_{3} \mathrm{PO}_{4}$ in this study, phase formation mechanisms in the infiltrated $\mathrm{Ca}(\mathrm{OH})_{2}$ specimen are discussed as follows.

(a) Liquids with a low $\mathrm{pH}$ value without any supersaturated precipitates

Infiltrated liquids such HP, HP2, LP, and LP2 do not contain any apparent supersaturated precipitates; therefore, when a porous $\mathrm{Ca}(\mathrm{OH})_{2}$ green powder compact are put inside these liquids, these liquids are expected to react with $\mathrm{Ca}(\mathrm{OH})_{2}$ instantaneously. This is because $\mathrm{Ca}(\mathrm{OH})_{2}$ is not a stable phase in a low $\mathrm{pH}$ aqueous solution. The dissolution rate of $\mathrm{Ca}(\mathrm{OH})_{2}$ is dependent of its solubility product $\left(\mathrm{K}_{\mathrm{sp}}\right)$ and the formation mechanisms of a new calcium orthophosphate phase, in which $\mathrm{K}_{\mathrm{sp}}=\left(\mathrm{Ca}^{2+}\right)_{\mathrm{aq}}\left(\mathrm{OH}^{-}\right)_{\mathrm{aq}}{ }^{2}$, $\left(\mathrm{Ca}^{2+}\right)_{\text {aq }}$ and $\left(\mathrm{OH}^{-}\right)_{\text {aq }}$ are the concentrations of $\mathrm{Ca}^{2+}$ and $\mathrm{OH}^{-}$ in the aqueous solution (aq), respectively.

From solubility product $\left(\mathrm{K}_{\mathrm{sp}}\right)$, when a $\mathrm{Ca}(\mathrm{OH})_{2}$ powder compact is impregnated in a low $\mathrm{pH}$ solution or a not supersaturated solution, such as a $\mathrm{H}_{3} \mathrm{PO}_{4}$ solution (LP or HP liquid), $\left(\mathrm{OH}^{-}\right)_{\text {aq }}$ is very low; subsequently for maintaining a constant $\mathrm{K}_{\mathrm{sp}}$, more $\mathrm{Ca}(\mathrm{OH})_{2}$ powders should be dissolved to increase $\left(\mathrm{Ca}^{2+}\right)_{\mathrm{aq}}$. From the $\mathrm{pH}$ value listed in Table 1, the $\mathrm{Ca}(\mathrm{OH})_{2} / 0.06 \mathrm{M} \mathrm{H}_{3} \mathrm{PO}_{4}$ system (LP liquid) has a higher $\mathrm{pH}=1.89$, or a higher concentration of $\mathrm{OH}^{-}$than the $\mathrm{Ca}(\mathrm{OH})_{2} / 1.2 \mathrm{M} \mathrm{H}_{3} \mathrm{PO}_{4}$ system (HP liquid) with an $\mathrm{pH}=1.03$; therefore, the dissolution rate in the HP liquid is expected to be faster than that in the LP liquid. As the dissolution of $\mathrm{Ca}(\mathrm{OH})_{2}$ proceeds, $\left(\mathrm{Ca}^{2+}\right)_{\mathrm{aq}}$ and $\left(\mathrm{OH}^{-}\right)_{\mathrm{aq}}$ are increasing. Consequently a new equilibrium state of $\mathrm{H}_{3} \mathrm{PO}_{4} \leftrightarrow$ $\mathrm{H}^{+}+\mathrm{H}_{2} \mathrm{PO}_{4}^{-}$reaches at the $\mathrm{pKa}=2.12$ in the liquid, and new calcium orthophosphate crystals or precipitates will appear at the solid/liquid interface, in which the solid is the porous $\mathrm{Ca}(\mathrm{OH})_{2}$ powder compact. After reaching such conditions, except for $\mathrm{K}_{\mathrm{sp}}$, the dissolution rate of $\mathrm{Ca}(\mathrm{OH})_{2}$ is also dependent of the formation mechanisms of these new calcium orthophosphate precipitates.

For an $\mathrm{HP} / \mathrm{Ca}(\mathrm{OH})_{2}$ system, if a $0.5 \mathrm{~g} \mathrm{Ca}(\mathrm{OH})_{2}$ powder compact is impregnated in a $100 \mathrm{cc}$ HP liquid, it will be completely dissolved in the liquid, as shown in Fig. 1. This is because a new equilibrium state $\mathrm{H}_{3} \mathrm{PO}_{4} \leftrightarrow \mathrm{H}^{+}+\mathrm{H}_{2} \mathrm{PO}_{4}{ }^{-}$at $\mathrm{pKa}=2.12$ does not reach yet, which can be seen from the amount of $\mathrm{Ca}(\mathrm{OH})_{2}$ powder dissolution of liquid HP to HP2 as listed in Table 1. From liquid HP to HP2, the amount of $\mathrm{Ca}(\mathrm{OH})_{2}$ dissolution is $5 \mathrm{~g}$ in $165.0 \mathrm{cc}$ of $1.2 \mathrm{M} \mathrm{H}_{3} \mathrm{PO}_{4}$ to reach $\mathrm{pH}=2$; therefore, a complete dissolution of a $0.5 \mathrm{~g} \mathrm{Ca}(\mathrm{OH})_{2}$ green powder compact in $100 \mathrm{cc}$ of $1.2 \mathrm{MH}_{3} \mathrm{PO}_{4}$ should not be able to obtain an $\mathrm{pH}=2$. As to the $\mathrm{HP} 2 / \mathrm{Ca}(\mathrm{OH})_{2}$ system, some $\mathrm{Ca}(\mathrm{OH})_{2}$ powders are found to dissolve in the HP2 liquid, before reaching an equilibrium state $\mathrm{H}_{3} \mathrm{PO}_{4} \leftrightarrow$
$\mathrm{H}^{+}+\mathrm{H}_{2} \mathrm{PO}_{4}^{-}$or the infrastructure of MCPM $\left(\mathrm{Ca}\left(\mathrm{H}_{2} \mathrm{PO}_{4}\right)_{2} \cdot \mathrm{H}_{2} \mathrm{O}\right)$ to replace the backbone structure of $\mathrm{Ca}(\mathrm{OH})_{2}$ powders, Therefore, the infiltrated $\mathrm{Ca}(\mathrm{OH})_{2}$ specimen HP2 shows some dimension changes in Fig. 1. However, in the $\mathrm{LP} / \mathrm{Ca}(\mathrm{OH})_{2}$ and $\mathrm{LP} 2 / \mathrm{Ca}(\mathrm{OH})_{2}$ systems, LP and LP2 liquids only need a slight amount of $\mathrm{Ca}(\mathrm{OH})_{2}$ being dissolved in a $100 \mathrm{cc}$ liquid to reach a higher $\mathrm{pH}$, as listed in Table 1; therefore, the infiltrated $\mathrm{Ca}(\mathrm{OH})_{2}$ powder compacts don't show any apparent dimension changes in Fig. 1.

(b) Liquids with supersaturated precipitates

If an infiltrated liquid reaches the first equilibrium state of $\mathrm{H}_{3} \mathrm{PO}_{4} \leftrightarrow \quad \mathrm{H}^{+}+\mathrm{H}_{2} \mathrm{PO}_{4}^{-}$, during liquid infiltration, the infiltration front in the solid/liquid interface (solid for the porous $\mathrm{Ca}(\mathrm{OH})_{2}$ powder compact) can be schematically described in Fig. 5. As the liquid infiltration proceeds, $\mathrm{Ca}^{2+}$ and $\mathrm{OH}^{-}$ions are released to the solid/liquid interface due to the dissolution of the solid phase $\mathrm{Ca}(\mathrm{OH})_{2}$. The dissolution rate of $\mathrm{Ca}(\mathrm{OH})_{2}$ is initially dependent of pHs. However, the $\mathrm{OH}^{-}$ion release is not large enough to locally change the $\mathrm{pH}$ value of infiltrated liquid at the initial interface of $\mathrm{Ca}(\mathrm{OH})_{2} /$ liquid. Therefore, precipitates are formed from the reactions between $\mathrm{Ca}^{2+}$ from dissolution of $\mathrm{Ca}(\mathrm{OH})_{2}$ and an orthophosphate ion $\mathrm{H}_{2} \mathrm{PO}_{4}^{-}$from the incoming infiltrated liquid. Subsequently, the phases of infiltrated specimen at the surface are the same crystal structures as the solid or precipitates in the original supersaturated aqueous solution. Therefore, MCPM, DCPD, and HA appear at the surface of infiltrated specimens as $\mathrm{pH}$ increases. Overall, the chemical reactions between $\mathrm{Ca}(\mathrm{OH})_{2}$ and infiltrated liquid are classified to have three mechanisms: dissolution of $\mathrm{Ca}(\mathrm{OH})_{2}$, precipitation, and growth of new precipitates.

Among these three mechanisms for the chemical reactions of $\mathrm{Ca}(\mathrm{OH})_{2} /$ liquid mentioned above, the most important factor for a successful liquid infiltration is preliminarily related to the dissolution rate of $\mathrm{Ca}(\mathrm{OH})_{2}$ powders. As a result, for obtaining an intact infiltrated specimen, the dissolution rate of $\mathrm{Ca}(\mathrm{OH})_{2}$ powders should keep as low as possible, especially at a low $\mathrm{pH}$ liquid.

\section{(c) Functional graded materials}

For a low $\mathrm{pH}$ liquid infiltration, if a porous $\mathrm{Ca}(\mathrm{OH})_{2}$ can be continuously infiltrated with the supersaturated liquid, the reacted phases along the infiltration direction or in the thickness direction can be proposed as shown in Fig. 6. This layer-like microstructure is much easier to form under a lower phosphate concentration, because a smaller amount of $\mathrm{Ca}(\mathrm{OH})_{2}$ dissolution can cause a higher $\mathrm{pH}$ change, as listed in Table 1.

At the first stage of liquid infiltration, an equilibrium state $\mathrm{H}_{3} \mathrm{PO}_{4} \leftrightarrow \mathrm{H}^{+}+\mathrm{H}_{2} \mathrm{PO}_{4}{ }^{-}$of the infiltrated liquid can be reached at $\mathrm{pKa}=2.12$. Therefore, MCPM starts to appear in zone I shown in Fig. 6. As the liquid infiltration proceeds, more $\mathrm{Ca}(\mathrm{OH})_{2}$ reacts with the incoming infiltrated liquid from the open pore channels to increase its $\mathrm{pH}$ up to another equilibrium state of $\mathrm{H}_{2} \mathrm{PO}_{4}^{-} \leftrightarrow \mathrm{H}^{+}+\mathrm{HPO}_{4}{ }^{2-}$ at $\mathrm{pKa}=7.21$, and then DCPD begins to form in the zone II. As the liquid is 
further infiltrated into the porous $\mathrm{Ca}(\mathrm{OH})_{2}$ powder compact, the reacted infiltration liquid finally reaches to the other equilibrium state of $\mathrm{HPO}_{4}{ }^{2-} \leftrightarrow \mathrm{H}^{+}+\mathrm{PO}_{4}{ }^{3-}$ at $\mathrm{pKa}=11.77$, and $\mathrm{HA}$ is supposed to finally exist in zone III even if the intermediate phase such as OCP $\left(\mathrm{Ca}_{8}\left(\mathrm{HPO}_{4}\right)_{2}\left(\mathrm{PO}_{4}\right)_{4} \cdot 5 \mathrm{H}_{2} \mathrm{O}\right)$ or $\mathrm{CDHA}\left(\mathrm{Ca}_{10-\mathrm{x}}\left(\mathrm{HPO}_{4}\right)_{\mathrm{x}}\left(\mathrm{PO}_{4}\right)_{6-\mathrm{x}}(\mathrm{OH})_{2-\mathrm{x}}, 0<\mathrm{x}<1\right)$ is probably formed in the early transformation period.[1, 8-12]

\begin{tabular}{|c|c|c|}
\hline & $\mathrm{H}_{3} \mathrm{P}$ & iquid \\
\hline & Zone I & MCPM+Liquid I \\
\hline 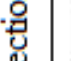 & Zone II & DCPD+Liquid II \\
\hline & Zone III & HA+Liquid III \\
\hline 列 & Unreacted zone & $\mathrm{Ca}(\mathrm{OH})_{2}$ \\
\hline
\end{tabular}

Figure 6. Proposed layer structures along the infiltration direction for a specimen being liquid infiltrated in a low concentration of $\mathrm{H}_{3} \mathrm{PO}_{4}$ solution.

Microstructures shown in Fig. 4 contain three different morphologies along the thickness direction in the fractographs of the infiltrated specimen LP, upper area and lower area in the reacted zone, and unreacted zone. In this $\mathrm{LP} / \mathrm{Ca}(\mathrm{OH})_{2}$ system, the upper area (zone I) has been identified as MCPM from the corresponding XRD shown in Fig. 2(a). As to the lower area (zone II), it is DCPD because a lower content of $\mathrm{P}$ but a higher content of $\mathrm{Ca}$ is determined from EDXSs shown in Figs. 4(b)-(d), by comparing it with the upper area (zone I). Except for EDXSs, an XRD for an infiltrated specimen at a higher $\mathrm{pH}=4$ (in the $\mathrm{LP} 4$ solution) also shows DCPD crystal structure at the infiltrated surface, as shown in Fig. 2(b). If the liquid can infiltrate further inside the $\mathrm{Ca}(\mathrm{OH})_{2}$ powder compact, HA or zone III can be obtained. Therefore, we believe a liquid infiltration method in the $\mathrm{Ca}(\mathrm{OH})_{2} / \mathrm{H}_{3} \mathrm{PO}_{4}$ can be used to fabricate a layer-like structure or a functional graded material.

\subsection{Correlations between Liquid Infiltration and Vapor Infiltration}

From SEM micrographs shown in Figs. 7(a), whisker morphologies are frequently being observed in the interface between the reacted and unreacted zones. This is because the chemical reaction between $\mathrm{Ca}(\mathrm{OH})_{2}$ and orthophosphate acid is an exothermic reaction during a liquid infiltration. For example, MCPM $\left(\mathrm{Ca}\left(\mathrm{H}_{2} \mathrm{PO}_{4}\right)_{2} \cdot \mathrm{H}_{2} \mathrm{O}\right)$ is formed by the following chemical reaction:

$$
\mathrm{Ca}(\mathrm{OH})_{2}+2 \mathrm{H}_{3} \mathrm{PO}_{4}=\mathrm{Ca}\left(\mathrm{H}_{2} \mathrm{PO}_{4}\right)_{2} \cdot \mathrm{H}_{2} \mathrm{O}+2 \mathrm{H}_{2} \mathrm{O}
$$

which occurs exothermically at low $\mathrm{pH}$ aqueous solution, $\mathrm{pH}<2[5,6,14,15]$. This exothermic reaction will locally heat up the surrounding liquids and materials. In the reaction front, the interface between the reacted zone (in the infiltrated liquid) and unreacted zone $\left(\mathrm{Ca}(\mathrm{OH})_{2}\right.$ powders), some infiltrated liquids (or orthophosphate solutions) become vapors to vapor infiltrate into the unreacted $\mathrm{Ca}(\mathrm{OH})_{2}$ powders. Therefore, in the system of $\mathrm{Ca}(\mathrm{OH})_{2}$ powder and $\mathrm{H}_{3} \mathrm{PO}_{4}$ liquid, some whiskers has been found in the reaction front, interface between the reacted zone and unreacted $\mathrm{Ca}(\mathrm{OH})_{2}$ zone, as shown in Fig. 7(a). From EDXS in Fig. 7(b), these whiskers contain $\mathrm{Ca}, \mathrm{P}$, and $\mathrm{O}$ elements; however, their morphologies are different from calcium orthophosphates in the liquid infiltration. The same whisker morphologies have been reported in some calcium orthophosphates being obtained from a chemical vapor deposition [16]. Therefore, it is believed that these whiskers are formed from a vapor reaction. While the infiltrated liquid reaches, these whiskers are expected to react with the liquid to transform into another phase, except for the area of closed pores. As a result, whiskers are difficult to find inside the reacted zone after liquid infiltration.

(a)

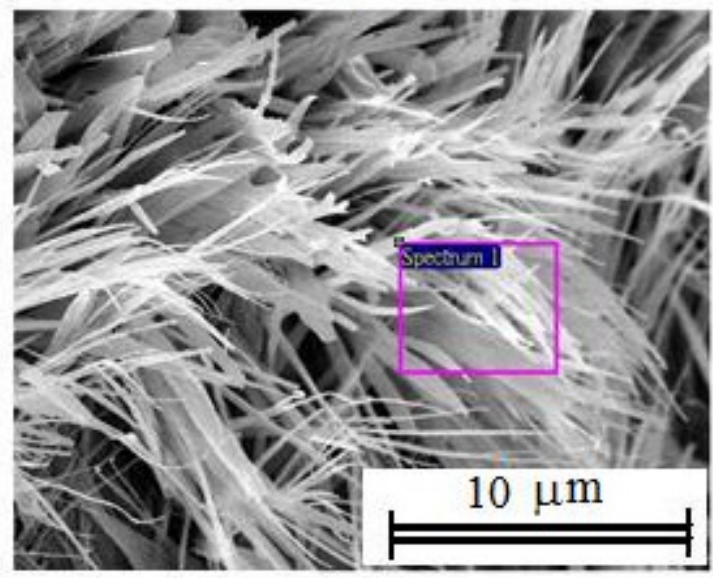

(b)

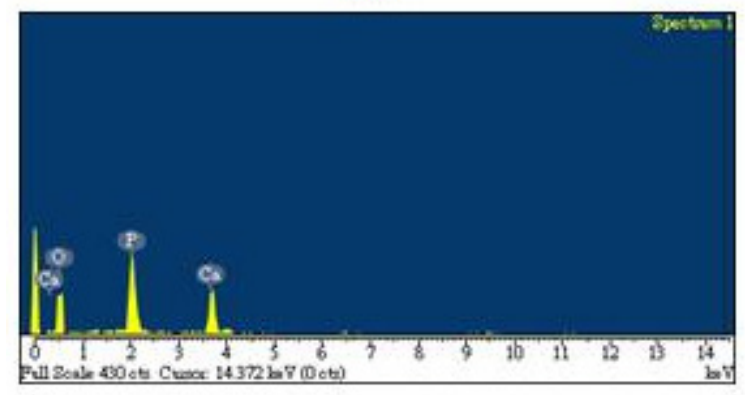

Figure 7. (a) Whiskers formed in the interface between the reacted and unreacted zones, and (b) its corresponding EDXS.

\subsection{Time Effect of $\mathrm{Ca}(\mathrm{OH})_{2}$ Green Powder Compact in the Air}

If $\mathrm{Ca}(\mathrm{OH})_{2}$ green powder compacts are put in the air for a period of time, some of $\mathrm{Ca}(\mathrm{OH})_{2}$ powders are transformed into the $\mathrm{CaCO}_{3}$ phase, as shown in Fig.8(b). This is because $\mathrm{Ca}(\mathrm{OH})_{2}$ can absorb $\mathrm{CO}_{2}$ from the environment to transform into $\mathrm{CaCO}_{3}$. From the comparisons of phase existence shown in Figs.8(a)-8(b), it indicates that $\mathrm{CaCO}_{3}$ in the initial 
powders is a minor phase, but it becomes a major phase after these $\mathrm{Ca}(\mathrm{OH})_{2}$ green powder compacts have been left in the air for a week. During a higher $\mathrm{pH}$ orthophosphate liquid infiltration, $\mathrm{CaCO}_{3}$ remains inside the infiltrated specimen and it is not transformed into any calcium orthophosphate phase, as shown in Fig.8(c). From X-ray diffraction patterns in Figs.8(b)-8(c), it shows that hydroxyapatite (HA) is from $\mathrm{Ca}(\mathrm{OH})_{2}$ not from $\mathrm{Ca}\left(\mathrm{CO}_{3}\right)_{2}$. However, $\mathrm{Ca}\left(\mathrm{CO}_{3}\right)_{2}$ can be dissolved in a very low $\mathrm{pH}$ orthophosphate liquid; therefore, it does not remain in the liquid infiltrated specimens.

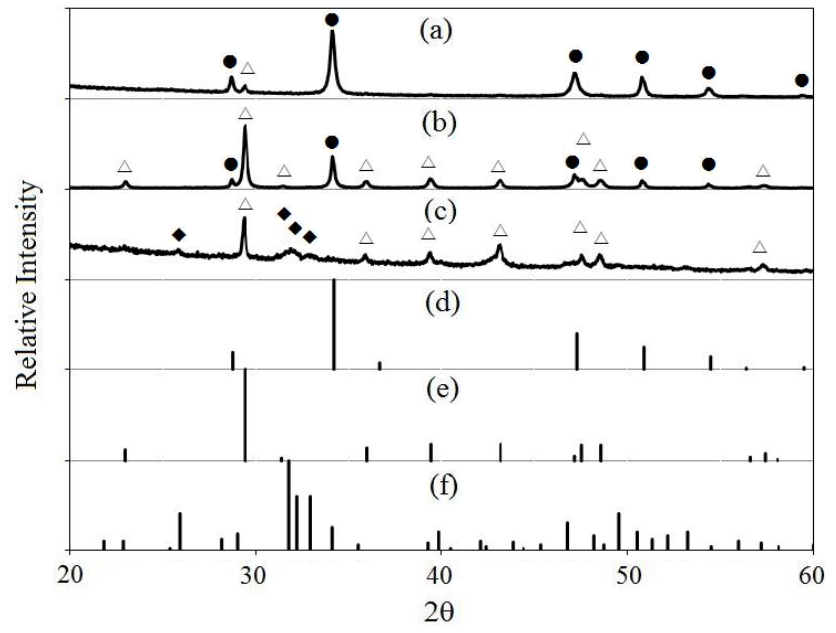

Figure 8. X-ray diffraction patterns for (a) the initial $\mathrm{Ca}(\mathrm{OH})_{2}$ green compact, (b) a $\mathrm{Ca}(\mathrm{OH})_{2}$ green compact in the air for a week, (c) the $\mathrm{CaCO}_{3}$-containing $\mathrm{Ca}(\mathrm{OH})_{2}$ green compact after the liquid infiltration at $\mathrm{pH}=12$, (d) $\mathrm{Ca}(\mathrm{OH})_{2}$ (JCPDS 72-0156), (e) $\mathrm{CaCO}_{3}$ (JCPDS 05-0586), (f) $\mathrm{Ca}_{10}\left(\mathrm{PO}_{4}\right)_{6}(\mathrm{OH})_{2}$ (HA, JCPDS 09-432). Symbols "O" are for $\mathrm{Ca}(\mathrm{OH})_{2}$, " $\triangle$ " for $\mathrm{CaCO}_{3}$, and " $"$ " for HA.

\section{Conclusions}

Several aqueous solutions with a different ratio of $\mathrm{Ca}(\mathrm{OH})_{2} / \mathrm{H}_{3} \mathrm{PO}_{4}$ were designed to infiltrate into the $\mathrm{Ca}(\mathrm{OH})_{2}$ green powder compacts from $\mathrm{pH}=1$ to $\mathrm{pH}=12$. An intact shape of bulk infiltrated specimen was obtained without any significant dimension or shape changes when a low concentration of $\mathrm{H}_{3} \mathrm{PO}_{4}$ or a liquid with $\mathrm{pH}>2$ was used.

Upon an infiltrated aqueous solution with the supersaturated calcium orthophosphate solids or precipitates, the infiltrated specimens showed their reacted phases at the surface similar to these supersaturated precipitates, which were $\mathrm{MCPM} \quad\left(\mathrm{Ca}\left(\mathrm{H}_{2} \mathrm{PO}_{4}\right)_{2} \cdot \mathrm{H}_{2} \mathrm{O}\right)$ to $\operatorname{DCPD}\left(\mathrm{CaHPO}_{4} \cdot 2 \mathrm{H}_{2} \mathrm{O}\right)$, and further to $\mathrm{HA}\left(\mathrm{Ca}_{10}\left(\mathrm{PO}_{4}\right)_{6}(\mathrm{OH})_{2}\right)$ as $\mathrm{pH}$ was increasing.

With a continuing liquid infiltration in the $\mathrm{Ca}(\mathrm{OH})_{2} / 0.06 \mathrm{MH}_{3} \mathrm{PO}_{4}$ system, the infiltrated specimen contained several different morphologies in its corresponding SEM fractographs. Inside the reacted zone, different concentrations of $\mathrm{Ca}, \mathrm{O}$, and $\mathrm{P}$ elements were observed in the two different areas: MCPM for the upper reacted area, and DCPD for the lower reacted area. If the liquid could infiltrate deeper enough, a layer structure of HA was proposed. Based on the above findings, a functional graded calcium orthophosphate material was obtained in the liquid with a very low concentration of $\mathrm{H}_{3} \mathrm{PO}_{4}$.

Except for the above SEM micrographs, some whiskers were frequently found at the interface between the reacted and unreacted zones in the $\mathrm{Ca}(\mathrm{OH})_{2} / 0.06 \mathrm{MH}_{3} \mathrm{PO}_{4}$ system. $\mathrm{CaCO}_{3}$ was also being observed if the $\mathrm{Ca}(\mathrm{OH})_{2}$ green powder compact had been exposed in the air for a period of time. This $\mathrm{CaCO}_{3}$ phase was not transformed into any orthophosphates during a liquid infiltration at higher $\mathrm{pHs}$. Overall, through a liquid infiltration in this study, different bulk calcium orthophosphate biomaterials were easy to synthesize at room temperature without any further sintering.

\section{Acknowledgements}

The authors would like to thank for High Value Instrument Center at I-Shou University for assisting to analyze X-ray diffraction patterns, SEM micrographs, and energy dispersive X-ray spectra (EDXS).

\section{REFERENCES}

[1] S. V. Dorozhkin. Calcium orthophosphate occurrence, properties, biomineralization, pathological calcification and biomimetic applications, Biomatter, Vol.1, No.2, 121-164, 2011

[2] R. I. Martin, P. W. Brown. Phase equilibria among acid calcium phosphates, Journal of the American Ceramic Society, Vol.80, 1263-1266, 1997.

[3] P. W. Brown. Phase relationships in the ternary system CaO- $\mathrm{P}_{2} \mathrm{O}_{5}-\mathrm{H}_{2} \mathrm{O}$ at $25^{\circ} \mathrm{C}$, Journal of the American Ceramic Society, Vol.75, 17-22, 1992.

[4] H. McDowell, T. M. Gregory, W. E. Brown. Solubility of $\mathrm{Ca}_{5}\left(\mathrm{PO}_{4}\right)_{3} \mathrm{OH}$ in the system $\mathrm{Ca}(\mathrm{OH})_{2}-\mathrm{H}_{3} \mathrm{PO}_{4}-\mathrm{H}_{2} \mathrm{O}$ at 5,15 , 25 and $37^{\circ} \mathrm{C}$, Journal of Research of the National Bureau of Standards, Sect A Phys Chem, Vol.81, 273-281, 1997.

[5] L. C. Chow. Next generation calcium phosphate-based biomaterials. Dental Materials Journal, Vol.28, 1-10, 2009.

[6] K. Ishikawa. Bone substitute fabrication based on dissolution-precipitation reactions, Materials, Vol. 3, 1138-1155, 2010.

[7] Y. C. Chang, T. S. Sheu. Precipitation mechanisms of hydroxyapatite powder in the different aqueous solutions, Ceramic Engineering \& Science Proceedings, Vol.27, No.6, 129-139, 2006.

[8] A. L. Boskey, A. S. Posner. Conversion of amorphous calcium phosphate to microcrystalline hydroxyapatite. A pH-dependent, solution -mediated, solid-solid conversion, Journal of Physical Chemistry, Vol.77, 2313-2317, 1973.

[9] N. Ito, M. Kamitakahara, S. Murakami, N. Watanabe, K. Ioku. Hydrothermal synthesis and characterization of 
hydroxyapatite from octacalcium phosphate. Journal of the Ceramic Society of Japan, Vol.118, 762-766, 2010.

[10] A. Nakahira, S. Aoki, K. Sakamoto, S. Yamaguchi. Synthesis and evaluation of various layered octacalcium phosphates by wet-chemical processing. Journal of Materials Science Materials in Medicine, Vol.12, 793-800, 2001.

[11] M. J. Arellano-Jimenez, R. Garcia-Garcia, J. Reyes-Gasga. Synthesis and hydrolysis of octacalcium phosphate and its characterization by electron microscopy and X-ray diffraction, Journal of Physics and Chemistry of Solids, Vol.70, 390-395, 2009.

[12] V. A. Sinyaev, E. S. Shustikova, L. V. Levchenko, A. A. Sedunov. AA (2009) Synthesis and dehydration of amorphous calcium phosphate, Inorganic Materials, Vol.37, 619-622, 2009.
[13] B. Leon, J. J. Jansen. Thin calcium phosphate coatings for medical implants, Springer: New York USA, pp.15, 2009.

[14] S. V. Dorozhkin. Calcium orthophosphates in nature, biology and medicine, Materials, Vol.2, 399-498, 2009.

[15] K. Ohura, M. Bohner, P. Hardouin, J. Lemaitre, G. Pasquier, B. Flautre. Resorption of, and bone formation from, new $\beta$-tricalcium phosphate-monocalcium phosphate cements: an in vivo study, Journal of Biomedical Materials Research, Vol.30, 193-200, 1996.

[16] H. R. Bakhsheshi-Rad, M. H. Idris, M. R. Abdul-Kadir. Synthesis and in vitro degradation evaluation of the nano- $\mathrm{HA} / \mathrm{MgF}_{2}$ and $\mathrm{DCPD} / \mathrm{MgF}_{2}$ composite coating on biodegradable $\mathrm{Mg}-\mathrm{Ca}-\mathrm{Zn}$ alloy, Surface and Coating Technology, Vol.222, 79-89, 2013. 